\title{
Discovery of pyrido[3,4-g]quinazoline derivatives as CMGC family protein kinase inhibitors: Design, synthesis, inhibitory potency and $X$-ray co-crystal structure
}

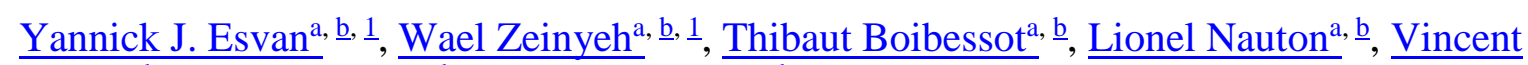
Théry $^{\mathrm{a}}, \underline{b}, \underline{\text { Stefan Knapp }}{ }^{\mathrm{c}, \mathrm{d}}$, Apirat Chaikuad $^{\mathrm{c}, \mathrm{d}}$, Nadège Loaëc $^{\mathrm{e}}, \underline{\text { Laurent Meijer }}$, Fabrice

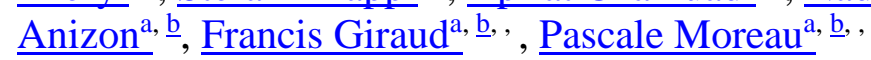

\section{Highlights}

- New pyrido[3,4-g]quinazoline derivatives were synthesized.

- Compounds $\mathbf{1 2}$ and $\mathbf{1 3}$ are nanomolar CLK1 and/or DYRK1A inhibitors.

- Co-crystal structures of $\mathbf{1 3}$ and $\mathbf{1 4}$ in CLK1 ATP-binding site were obtained.

\section{Abstract}

The design and synthesis of new pyrido[3,4-g]quinazoline derivatives is described as well as their protein kinase inhibitory potencies toward five CMGC family members (CDK5, CK1, GSK3, CLK1 and DYRK1A). The interest for this original tricyclic heteroaromatic scaffold as modulators of CLK1/DYRK1A activity was validated by nanomolar potencies (compounds 12 and 13). CLK1 co-crystal structures with two inhibitors revealed the binding mode of these compounds within the ATP-binding pocket.

\section{Graphical abstract}
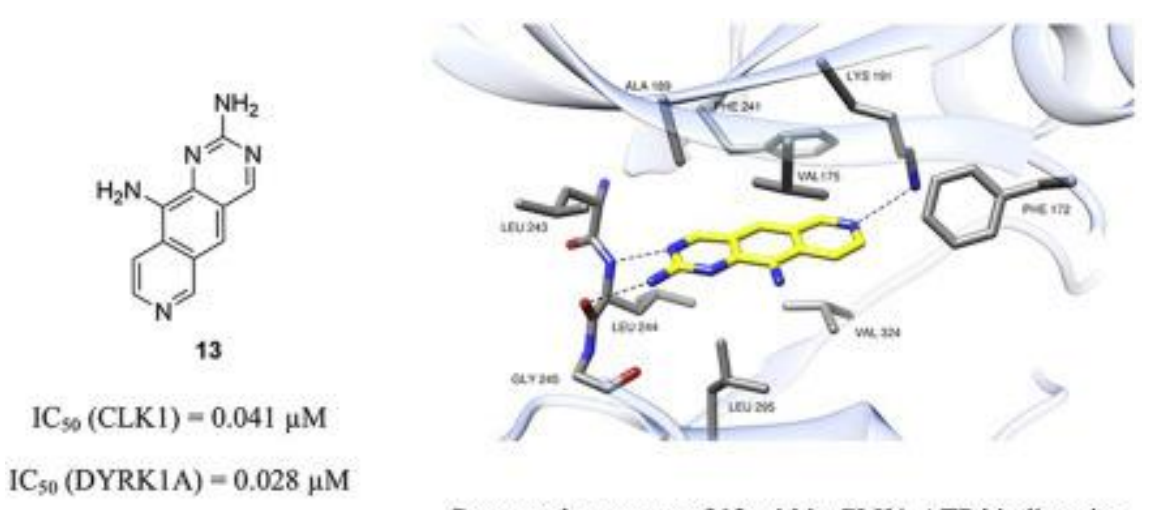

Co-crystal structure of 13 within CLKI-ATP binding site

\section{Keywords}

- Pyrido[3,4-g]quinazoline; 
- Kinase inhibitors;

- Ser/Thr kinases;

- CMGC family;

- CLK1 binding mode

\section{Introduction}

Alzheimer's disease (AD) is expanding dramatically in association with population ageing. This neurodegenerative disorder is characterized by the apparition of intracellular neurofibrillary tangles containing microtubule associated Tau proteins and extracellular amyloid plaques that accumulate in brain. The control of microtubule stabilization is mediated by Tau interaction with tubulin and phosphorylation; abnormal phosphorylation of Tau could lead to neuronal cytoskeleton disruption. Additionally, increased phosphorylation of Tau leads to its aggregation into filaments that could be responsible for neuronal death [1] and [2]. Various protein kinases participate in the regulation of Tau by site-specific phosphorylation. CDK5, CK1, GSK3 and DYRK1A are involved in the formation of neurofibrillary tangles by abnormal Tau phosphorylation on AD-specific sites leading to the formation of filaments [3], [4], [5], [6] and [7]. Moreover, CLK1 and DYRK1A participate in alternative pre-mRNA splicing, a physiological process that is altered in AD [8] and [9]. Due to the important physiological functions of these kinases, the development of multi-target directed ligands (MTDLs), inhibitors that could target more than one of them, is of high interest and may allow the development of new biological tools/therapies to better understand/treat AD [10].

Meridianins A-G (Fig. 1A), indolic derivatives substituted by a 2-aminopyrimidine ring, are natural products isolated from Aplidium meridianum ascidiae [11], [12] and [13]. Recently, we described the synthesis of diversely substituted meridianin $G$ analogues. In order to identify new tools to study AD, these compounds were evaluated on a panel of five ADrelevant members of the Ser/Thr kinases CMGC family (CDK5, CK1, GSK3, CLK1, DYRK1A) (Fig. 1B) [14], [15], [16] and [17].

A)

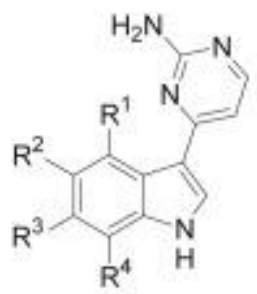

Meridianin $A \quad R^{1}=O H, R^{2}=H, R^{3}=H, R^{4}=H$

Meridianin $B \quad R^{1}=O H, R^{2}=H, R^{3}=B r, R^{4}=H$

Meridianin $C \mathrm{R}^{1}=\mathrm{H}, \mathrm{R}^{2}=\mathrm{Br}, \mathrm{R}^{3}=\mathrm{H}, \mathrm{R}^{4}=\mathrm{H}$

Meridianin $D R^{1}=H, R^{2}=H, R^{3}=B r, R^{4}=H$

Meridianin $E R^{1}=O H, R^{2}=H_{1} R^{3}=H_{1} R^{4}=B r$

Meridianin $F \quad R^{1}=H, R^{2}=B r, R^{3}=B r, R^{4}=H$

Meridianin $G R^{1}=H, R^{2}=H, R^{3}=H, R^{4}=H$
B)
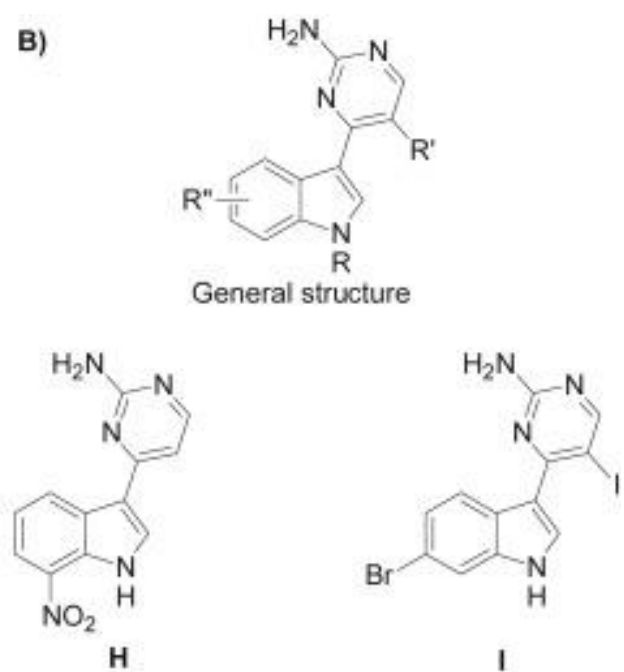

Fig. 1. 
A) Chemical structure of meridianins $A-G, B)$ General structure of meridianin analogues and two DYRK1A/CLK1 inhibitors $(\mathbf{H}, \mathbf{I})$ described by our group.

The structure-activity relationship study performed on meridianin derivatives showed that the introduction of a bromine atom or a nitro group at the 6- or 7-position of the indolic moiety could result in DYRK1A/CLK1 inhibitors with nanomolar potencies (Fig. 1B, compounds $\mathbf{H}$, I). Because of these interesting results, we decided to extend the structure-activity relationship study in this aminopyrimidine series. The putative binding mode between the ATP binding site of CLK1/DYRK1A and most active compounds of the series revealed that the aminopyrimidine moiety was oriented toward the bottom of the ATP-binding pocket, establishing two hydrogen bonds with the hinge [17]. In order to develop a second generation of inhibitors, we first decided to restrict the conformation between the aminopyrimidine and indole moieties. For this purpose these rings were connected by an additional phenyl ring. Next, we noticed that the 3-aminopyrimidinylindole chemical scaffold could be simplified by removing the pyrrole moiety that is not directly involved in the molecular interaction within the ATP-binding pocket. Finally, a pyridine moiety was introduced to reinforce the Hbonding network within the ATP-binding site (Fig. 2).

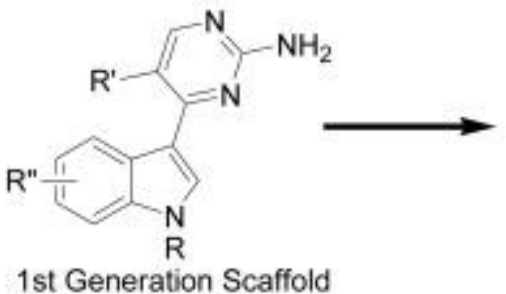

Fig. 2.

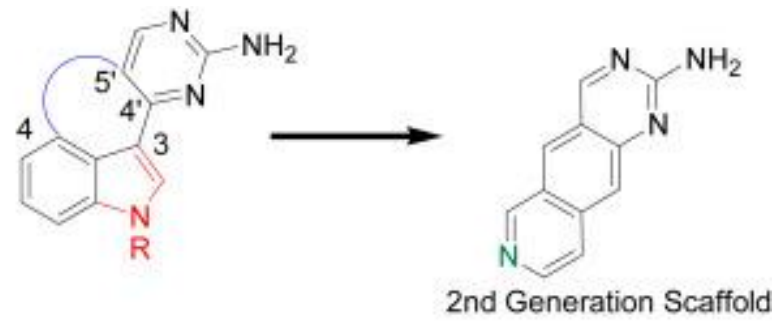

Design of the second generation scaffold.

To validate this model, the synthesis of this novel pyrido[3,4-g]quinazoline series was undertaken. The inhibitory potency of new compounds on a panel of five kinases $(\mathrm{CDK} 5 / \mathrm{p} 25, \mathrm{CK} 1 \delta / \varepsilon, \mathrm{GSK}-3 \alpha / \beta$, DYRK1A and CLK1) was examined. To interact with targeted kinases, potential inhibitors should cross the blood-brain barrier (BBB) therefore physical properties that influence BBB permeability were also calculated. Finally the binding mode of this series within the CLK1 ATP-binding pocket was elucidated by X-ray crystallography.

\section{Results and discussion}

The preparation of the targeted molecules (Scheme 1) starts from commercially available 2chloro-4-nitrobenzoic acid $\mathbf{1}$ that was first esterified using ethanol in the presence of sulfuric acid to give $\mathbf{2}$ in $98 \%$ yield. The reduction of the nitro group [18] of $\mathbf{2}$ led to amino derivative 3 that was iodinated by treatment with iodine and silver sulfate [19] to give $\mathbf{4}$, as the major regioisomer, in $65 \%$ yield. The $\mathrm{CuCN}$-mediated cyanation of 4 was performed in good yield utilizing a modified Rosenmund-von Braun procedure in the presence of 1-proline according to Wang et al. [20]. Next, the amino group of $\mathbf{5}$ was substituted using a Sandmeyer type reaction to give its iodo analogue $\mathbf{6}$ in $84 \%$ yield [21]. The treatment of $\mathbf{6}$ by DIBAL-H led to 7 in $87 \%$ yield by ester and nitrile reduction [22]. Then, Sonogashira cross-coupling reaction of 7 with TMS-acetylene gave compound 8 in 87\% yield [23] and [24]. The isoquinoline moiety was formed under microwave irradiation of $\mathbf{8}$ in the presence of ammonia in methanol 
[25]. Finally, oxidation of 9 using $\mathrm{MnO}_{2}$ led to 6-chloroisoquinoline-7-carbaldehyde $\mathbf{1 0}$ in $88 \%$ yield ( Scheme 1) [26].<smiles>CCOC(=O)c1cccc(Nc2ccc(C(=O)OCC)c(Cl)c2)c1</smiles>

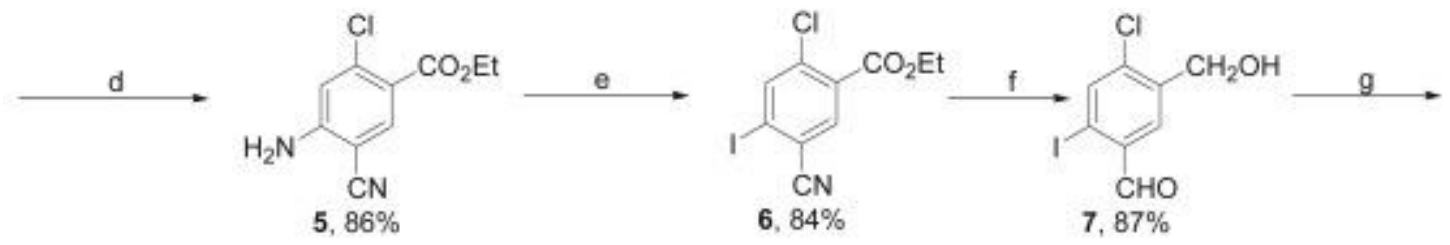<smiles>CC#Cc1cc(Cl)c(CO)cc1[C@H](C)O</smiles>

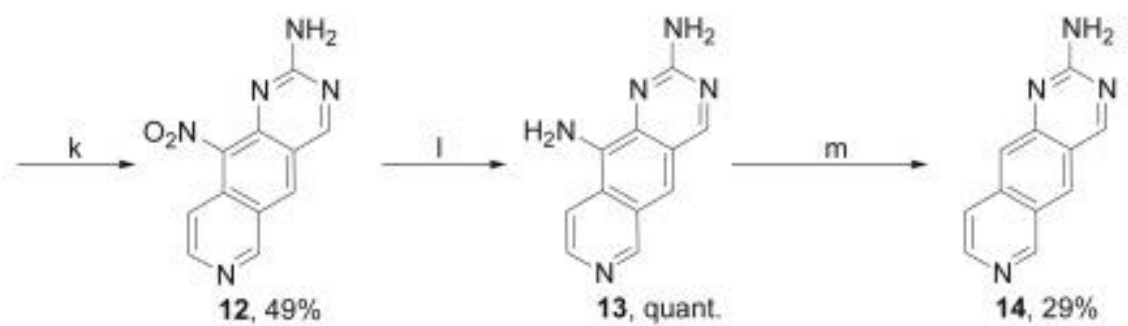

Scheme 1.

Synthesis of compounds 12-14. Reagents and conditions: (a) EtOH, $\mathrm{H}_{2} \mathrm{SO}_{4}$ (b) Fe, $\mathrm{NH}_{4} \mathrm{Cl}, i \mathrm{PrOH} / \mathrm{H}_{2} \mathrm{O}$ (c) $\mathrm{I}_{2}, \mathrm{Ag}_{2} \mathrm{SO}_{4}, \mathrm{EtOH}$ (d) CuCN, 1-proline, DMF (e) Isoamylnitrite, $\mathrm{CH}_{2} \mathrm{I}_{2}$ (f) DIBAL-H, toluene (g) TMS-acetylene, $\mathrm{PdCl}_{2}\left(\mathrm{PPh}_{3}\right)_{2}, \mathrm{CuI}$, $\mathrm{Et}_{3} \mathrm{~N}$ (h) $\mathrm{NH}_{3}, \mathrm{MeOH}$, $\mu$ w (i) $\mathrm{MnO}_{2}, \mathrm{CHCl}_{3}$ (j) $\mathrm{HNO}_{3}, \mathrm{H}_{2} \mathrm{SO}_{4}$ (k) Guanidine. $\mathrm{H}_{2} \mathrm{CO}_{3}$, DMF (l) $\mathrm{H}_{2}, \mathrm{Pd} / \mathrm{C}, \mathrm{CH}_{2} \mathrm{Cl}_{2} / \mathrm{MeOH}$ (m) $\mathrm{NaNO}_{2}, \mathrm{H}_{3} \mathrm{PO}_{2}, \mathrm{HCl} / \mathrm{H}_{2} \mathrm{O}$.

The formation of the aminopyrimidine part was initially envisaged by reacting chloroaldehyde $\mathbf{1 0}$ with a guanidine salt. However, under the conditions tested, we never managed to get the expected aminopyrimidine. Therefore, in order to get a more activated product for the cyclization, a nitro group was regioselectively introduced on compound $\mathbf{1 0}$ leading to 11.

Then, as anticipated the coupling reaction between $\mathbf{1 1}$ and guanidine carbonate was successful and led to the tricyclic derivative 12 in an acceptable yield [27]. The removal of the nitro group was performed in two steps by catalytic hydrogenation of $\mathbf{1 2}$ leading to $\mathbf{1 3}$ that was diazotized to produce the corresponding diazonium salt. This latter was quenched by hypophosphorous acid to give derivative $\mathbf{1 4}[28]$. 
The inhibitory potency toward CDK5/p25, CK $1 \delta / \varepsilon$, GSK-3 $\alpha / \beta$, DYRK $1 \mathrm{~A}$ and CLK 1 of the first three representatives of this tricyclic series (compounds 12-14) were evaluated (Table 1). As indicated in Table 1, DYRK1A and CLK1 are the most efficiently inhibited kinases. Contrarily to 14, compounds 12 and 13 substituted by a nitro or amino function exhibited nanomolar potencies toward one or two kinases tested. This result indicated that the presence of a nitro or amino substitution is particularly important for CLK1/DYRK1A inhibition. Compound $\mathbf{1 3}$ bearing an amino function is the most potent DYRK1A/CLK1 inhibitor of the series. We have previously discussed on these two CMGC kinases family members that exhibit sequence homology (32.8\%) and a considerable ATP binding site sequence identity (70.4\%) [17]. Compound 12 showed a 10-fold higher activity toward CLK1 compared to DYRK1A and thus constitute an interesting tool to distinguish between CLK1 and DYRK1A functions.

\section{Table 1.}

Physicochemical properties and kinases inhibitory potencies ( $\mathrm{IC}_{50}$ in $\mu \mathrm{M}$ ) for compounds 12 14.

\begin{tabular}{|c|c|c|c|c|c|c|c|c|c|c|}
\hline \multirow[b]{2}{*}{ Cpds } & \multirow{2}{*}{$\begin{array}{l}\text { PSA } \\
\left(\AA^{2}\right)\end{array}$} & \multirow{2}{*}{\multicolumn{2}{|c|}{ HBD $\operatorname{clog} P$}} & \multirow{2}{*}{$\begin{array}{c}\operatorname{clog} D \\
\text { pH } 7.4\end{array}$} & \multirow{2}{*}{ MW } & \multicolumn{5}{|c|}{ Kinase inhibition - ICso in $\mu \mathrm{M}^{\mathrm{a}}$} \\
\hline & & & & & & CDK & 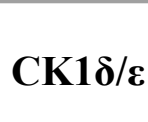 & $\begin{array}{c}\text { GSK- } \\
3 \alpha / \beta\end{array}$ & CLK1 & DYRK1A \\
\hline 12 & 211 & 2 & 0.64 & 0.99 & 241 & $>10$ & 0.78 & 2.2 & 0.069 & 0.62 \\
\hline 13 & 182 & 4 & 0.67 & 0.22 & 211 & 4.8 & 5.8 & 9.1 & 0.041 & 0.028 \\
\hline 14 & 132 & 2 & 0.90 & 1.05 & 196 & $>10$ & 0.8 & $>10$ & 0.19 & 0.18 \\
\hline Har ${ }^{\mathrm{b}}$ & - & - & - & - & - & 8 & 1.8 & $>10$ & 0.072 & 0.056 \\
\hline $\mathbf{L 4 1}^{\mathrm{b}}$ & - & - & - & - & - & $>10$ & $>10$ & 0.41 & 0.071 & 0.040 \\
\hline
\end{tabular}

a)Values are means of triplicate experiments.

b) Data given in Ref. [29] for harmine (Har) and leucettine 41 (L41).

To evaluate their ability to cross the BBB, compounds 12-14 physicochemical properties were calculated using Sybylx2.1 (Polar Surface Area (PSA), cLogP) [30] and MarvinSketch $(\log D)$. The calculated values ( Table 1) were compared to the required one for an optimized $\mathrm{BBB}$ penetration [31]. Molecular weights of 12-14 $(<500)$ are acceptable as well as the number of hydrogen bond donors (HBD). Actually, this number is preferred to be $<3$ to increase the BBB penetration. However, PSA of 12-14 are superior to the usually required values $\left(<90 \AA^{2}\right)$ while their $\operatorname{cog} P$ and $\operatorname{cog} D$ values are inferior to the requested ones $(2-5)$. Altogether, these results indicated that compounds 12-14 could be too hydrophilic, according to the usually admitted physicochemical properties for an optimal BBB crossing. This could be changed by the introduction of hydrophobic substituents such as alkyl, aryl groups or halogens.

Finally, to get structural data on the binding mode of this pyrido[3,4-g]quinazoline series, Xray crystal structures of compounds 13 and non-substituted analogue 14 were solved at $2.52 \AA$ and $2.42 \AA$, respectively. As shown in Fig. 3, compounds 13 and $\mathbf{1 4}$ adopt the same pose within the ATP-binding site of CLK1. The aminopyrimidine part is located in the hinge region and is $\mathrm{H}$-bonded to Leu244 backbone $\mathrm{NH}$ and carbonyl groups. A third H-bond is established between the pyridine nitrogen atom and the Lys 191 side chain amino group. In 
addition, hydrophobic interactions involve residues Val175, Leu295 and Val324. The 5-fold better activity of 13 over its unsubstituted analogue 14 could be partly explained by the amino group interactions within the kinase ATP-binding pocket. Indeed, the amino group of compound $\mathbf{1 3}$ is directed toward the ribose pocket and is probably involved in a large stabilizing $\mathrm{H}$-bonds network with water molecules.
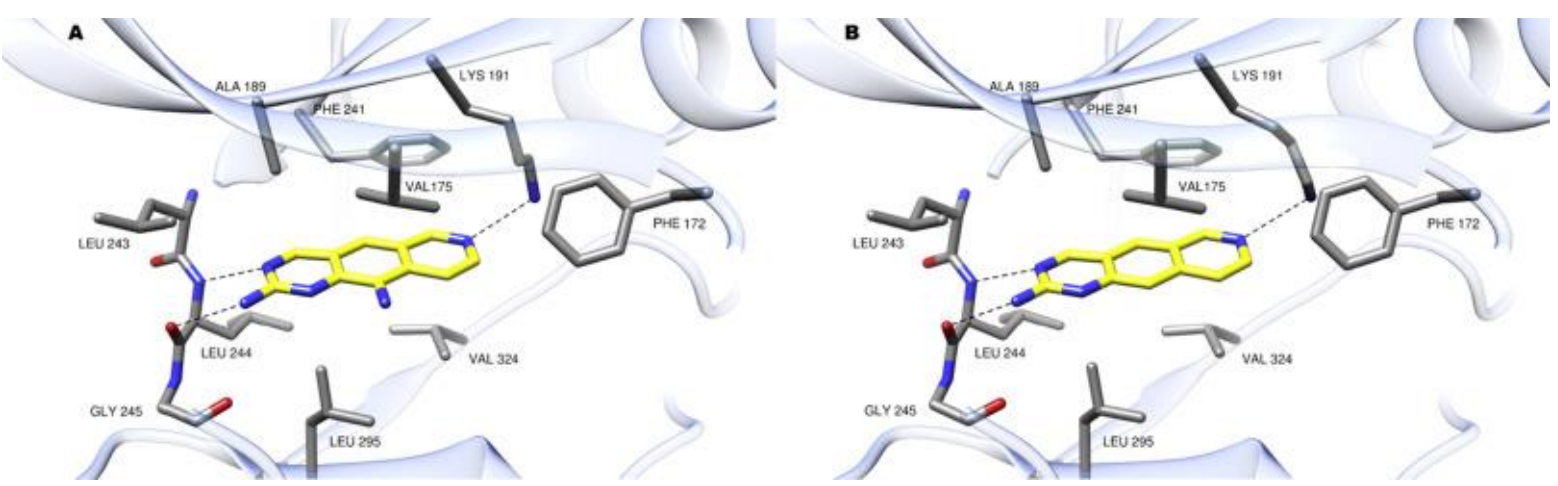

Fig. 3. : Co-crystal structures of compounds 13 (Fig. 3A) and 14 (Fig. 3B) with CLK1-ATP binding site. PDB codes:5J1V (13) and 5J1W (14). The hydrogen bonds are shown by dashed lines. The images were produced using UCSF Chimera [32].

\section{Conclusion}

In our efforts to design original aza-heterocyclic compounds as potent protein kinase inhibitors, a new series of pyrido[3,4-g]quinazolines was synthesized and evaluated on five members of the CMGC family. Two derivatives (12 and 13) demonstrated nanomolar potencies toward CLK1 and/or DYRK1A. This preliminary work identified a new scaffold to target CLK1/DYRK1A kinases. The binding mode of this series with CLK1 was elucidated by X-ray crystallography. Taking into account these structural information and in order to reach an improved physicochemical profile in this series, the enlargement of the structureactivity relationship study is currently under investigation in our group. In addition complementary cellular assays will be undertaken to further examine the biological profile of this series.

\section{Experimental section}

\subsection{Chemistry}

\subsubsection{General}

Starting materials were obtained from commercial suppliers and used without further purification. Experiments under microwave irradiation were performed using a CEM Discover Benchmate apparatus. IR spectra were recorded on a Shimadzu FTIR-8400S or Perkin-Elmer Spectrum 65 FT-IR spectrometers $\left(\bar{\nu} v^{-}\right.$in $\left.\mathrm{cm}^{-1}\right)$. NMR spectra, performed on a Bruker AVANCE $400\left({ }^{1} \mathrm{H}: 400 \mathrm{MHz},{ }^{13} \mathrm{C}: 100 \mathrm{MHz}\right)$, or a Bruker AVANCE $500\left({ }^{1} \mathrm{H}\right.$ : $500 \mathrm{MHz}$ ), are reported in ppm using the solvent residual peak as an internal standard; the following abbreviations are used: singlet (s), doublet (d), triplet (t), quadruplet (q), doublet of doublet (dd), doublet of triplet (dt), broad signal (br s). High resolution mass spectra (ESI+) were determined on a high-resolution Waters Micro Q-Tof or Thermo Scientific Q Exactive Q-Orbitrap apparatus (UBP-START, Université Blaise Pascal, Clermont-Ferrand, France). 
Chromatographic purifications were performed by column chromatography using 40-63 $\mu \mathrm{m}$ silica gel. Reactions were monitored by TLC using fluorescent silica gel plates (60 F254 from Merck). Melting points were measured on a Stuart SMP3 apparatus and are uncorrected.

The purity of compounds $\mathbf{1 2}-\mathbf{1 4}$ was established to be $\geq 95 \%$ by HPLC analysis using a Dionex liquid chromatograph (TTC-100, $30{ }^{\circ} \mathrm{C}$; P580; UVD340U) and a C18 Uptisphere ODB Interchim column $(4.6 \mathrm{~mm} \times 250 \mathrm{~mm}, 5 \mu \mathrm{m}, 120 \AA)$. Detection wavelength was $280 \mathrm{~nm}$, and flow rate $0.5 \mathrm{~mL} / \mathrm{min}$. Solvents were (A) water; (B) water $/ 0.1 \% \mathrm{TFA}$; (C) acetonitrile; (D) methanol; three methods were used: method I, 95:5 B/C for 5 min then 95:5 B/C to $5: 95 \mathrm{~B} / \mathrm{C}$ in $20 \mathrm{~min}$ and then $5: 95 \mathrm{~B} / \mathrm{C}$ for $5 \mathrm{~min}$; method II, 40:60 A/D in an isocratic mode. For method III, HPLC analysis was performed using an Agilent HP 1100 liquid chromatograph (ambient temperature) and a C18 Uptisphere ODB Interchim column (4.6 $\mathrm{mm} \times 250 \mathrm{~mm}, 5 \mu \mathrm{m}, 120 \AA$ ). Detection wavelength was $254 \mathrm{~nm}$, flow rate $0.5 \mathrm{~mL} / \mathrm{min}$ and $40: 60 \mathrm{~B} / \mathrm{C}$ in an isocratic mode.

\subsubsection{Ethyl 2-chloro-4-nitrobenzoate (2)}

To a solution of 2-chloro-4-nitrobenzoic acid (20 g, $99.2 \mathrm{mmol}, 1.0$ equiv) in anhydrous ethanol $(160 \mathrm{~mL})$ was added $\mathrm{H}_{2} \mathrm{SO}_{4}(8 \mathrm{~mL}, 1.5$ equiv). After stirring overnight at reflux, water was added, the reaction mixture was concentrated and the product was extracted with EtOAc. The combined organic layers were washed with an aqueous solution of $\mathrm{NaOH}(1 \mathrm{M})$, dried over $\mathrm{MgSO}_{4}$, filtered and concentrated under reduced pressure. Without any purification, compound $2(22.4 \mathrm{~g}, 97.5 \mathrm{mmol}, 98 \%)$ was obtained as a pale yellowish oil. $R f=0.8$ (EtOAc/cyclohexane 1:2). IR (ATR): 1733, 1526, 1350, $1246 \mathrm{~cm}^{-1} ;{ }^{1} \mathrm{H}$ NMR $\left(400 \mathrm{MHz}, \mathrm{DMSO}-d_{6}\right): 1.33(3 \mathrm{H}, \mathrm{t}, J=7.2 \mathrm{~Hz}), 4.38(2 \mathrm{H}, \mathrm{q}, J=7.2 \mathrm{~Hz}), 8.03(1 \mathrm{H}, \mathrm{d}$, $J=8.4 \mathrm{~Hz}), 8.27\left(1 \mathrm{H}, \mathrm{dd}, J_{l}=8.4 \mathrm{~Hz}, J_{2}=2.4 \mathrm{~Hz}\right), 8.38(1 \mathrm{H}, \mathrm{d}, J=2.4 \mathrm{~Hz}) ;{ }^{13} \mathrm{C} \mathrm{NMR}$ (100 MHz, DMSO-d $)$ : $13.9\left(\mathrm{CH}_{3}\right), 62.2\left(\mathrm{CH}_{2}\right), 122.4,125.4,131.8\left(\mathrm{CH}_{\text {arom }}\right), 132.3,136.2$, $149.3\left(\mathrm{C}_{\text {arom }}\right), 164.0(\mathrm{CO})$; HRMS $\left(\mathrm{ESI}^{+}\right)$calcd for $\mathrm{C}_{9} \mathrm{H}_{8} \mathrm{ClNaNO}_{4}(\mathrm{M}+\mathrm{Na})^{+} 252.0040$, found 252.0052 .

\subsubsection{Ethyl 4-amino-2-chlorobenzoate (3)}

To a solution of compound $2(5.0 \mathrm{~g}, 21.8 \mathrm{mmol}, 1$ equiv $)$ in a 10:1 isopropanol/water mixture $(50 \mathrm{~mL})$ were successively added iron powder $(7.3 \mathrm{~g}, 131.2 \mathrm{mmol}, 6$ equiv) and ammonium chloride ( $0.46 \mathrm{~g}, 8.6 \mathrm{mmol}, 0.4$ equiv). The reaction mixture was heated at $80{ }^{\circ} \mathrm{C}$ for $45 \mathrm{~min}$ then filtered through Celite and washed with EtOAc and water. The filtrate was then extracted with EtOAc and the combined organic layers were dried over $\mathrm{MgSO}_{4}$, filtered and concentrated under reduced pressure. Without any purification, compound $\mathbf{3}$ (4.2 g, $21.2 \mathrm{mmol}, 97 \%$ ) was obtained as a yellowish powder. $R f=0.3$ (EtOAc/cyclohexane 1:3). Mp 109-111 ${ }^{\circ} \mathrm{C}$; IR (ATR): 3500-3200, 1698, 1597, $1244 \mathrm{~cm}^{-1}$; ${ }^{1} \mathrm{H}$ NMR (400 MHz, DMSO- $\left.d_{6}\right): 1.26(3 \mathrm{H}, \mathrm{t}, J=6.8 \mathrm{~Hz}), 4.19(2 \mathrm{H}, \mathrm{q}, J=6.8 \mathrm{~Hz}), 6.16(2 \mathrm{H}, \mathrm{br} \mathrm{s}), 6.50(1 \mathrm{H}, \mathrm{dd}$, $\left.J_{1}=8.8 \mathrm{~Hz}, J_{2}=2.4 \mathrm{~Hz}\right), 6.62(1 \mathrm{H}, \mathrm{d}, J=2.4 \mathrm{~Hz}), 7.63(1 \mathrm{H}, \mathrm{d}, J=8.8 \mathrm{~Hz}) ;{ }^{13} \mathrm{C} \mathrm{NMR}$ (100 MHz, DMSO-d $)$ : $14.2\left(\mathrm{CH}_{3}\right), 59.9\left(\mathrm{CH}_{2}\right), 111.5,114.5,133.5\left(\mathrm{CH}_{\text {arom }}\right), 114.1,134.7$, $153.4\left(\mathrm{C}_{\text {arom }}\right), 164.3(\mathrm{CO})$; HRMS $\left(\mathrm{ESI}^{+}\right)$calcd for $\mathrm{C}_{9} \mathrm{H}_{11} \mathrm{ClNO}_{2}(\mathrm{M}+\mathrm{H})^{+} 200.0478$, found 200.0484 .

\subsubsection{Ethyl 4-amino-2-chloro-5-iodobenzoate (4)}

To a solution of compound 3 (3.02 g, $15.1 \mathrm{mmol}$, 1 equiv) in anhydrous ethanol $(150 \mathrm{~mL})$ at $0{ }^{\circ} \mathrm{C}$ were added silver sulfate $(4.68 \mathrm{~g}, 15.1 \mathrm{mmol})$ and iodine $(3.81 \mathrm{~g}, 15.1 \mathrm{mmol})$. The 
solution was stirred for $45 \mathrm{~min}$ at $0{ }^{\circ} \mathrm{C}$ and additional $90 \mathrm{~min}$ at room temperature. After completion, a saturated aqueous sodium thiosulfate solution was added. The reaction mixture was filtered through Celite, washed with ethanol and filtrate was concentrated to dryness. Water was added and the product was extracted with EtOAc, the combined organic layers were dried over $\mathrm{MgSO}_{4}$, filtered and concentrated under reduced pressure. The crude product was triturated with cyclohexane and pentane yielding the compound 4 ( $3.18 \mathrm{~g}, 9.77 \mathrm{mmol}$, $65 \%$ ) as a brown powder. $R f=0.3$ (EtOAc/cyclohexane 1:9). Mp $125-127^{\circ} \mathrm{C}$; IR (ATR): $3470-3325,1702,1573,1242 \mathrm{~cm}^{-1} ;{ }^{1} \mathrm{H}$ NMR (400 MHz, DMSO- $\left.d_{6}\right): 1.27(3 \mathrm{H}, \mathrm{t}, J=6.8 \mathrm{~Hz})$, $4.21(2 \mathrm{H}, \mathrm{q}, J=6.8 \mathrm{~Hz}), 6.23\left(2 \mathrm{H}\right.$, br s), $6.78(1 \mathrm{H}, \mathrm{s}), 8.08(1 \mathrm{H}, \mathrm{s}) ;{ }^{13} \mathrm{C} \mathrm{NMR}(100 \mathrm{MHz}$, DMSO- $\left.d_{6}\right): 14.1\left(\mathrm{CH}_{3}\right), 60.4\left(\mathrm{CH}_{2}\right), 122.9,142.2\left(\mathrm{CH}_{\text {arom }}\right), 114.3,116.5,134.3,153.1\left(\mathrm{C}_{\text {arom }}\right)$, $163.0(\mathrm{CO})$; HRMS $\left(\mathrm{ESI}^{+}\right)$calcd for $\mathrm{C}_{9} \mathrm{H}_{10} \mathrm{ClINO}_{2}(\mathrm{M}+\mathrm{H})^{+} 325.9445$, found 325.9443 .

\subsubsection{Ethyl 4-amino-2-chloro-5-cyanobenzoate (5)}

To a solution of compound 4 (4.13 g, $12.7 \mathrm{mmol}, 1$ equiv) in $N, N$-dimethylformamide $(25 \mathrm{~mL})$ were added copper(I) cyanide $(2.27 \mathrm{~g}, 25.4 \mathrm{mmol}, 2$ equiv) and $l$-proline (1.46 g, $12.7 \mathrm{mmol}$ ). After stirring overnight at $80^{\circ} \mathrm{C}$, water and EtOAc were added. The resulting suspension was filtered through Celite and filtrate was extracted with EtOAc. The combined organic layers were dried over $\mathrm{MgSO}_{4}$, filtered and concentrated under reduced pressure. Trituration of the crude material with small amount of diisopropyl ether yielded the pure product $5(2.45 \mathrm{~g}, 10.9 \mathrm{mmol}, 86 \%)$ as a pale brown powder. $R f=0.5$ (EtOAc/cyclohexane 1:2). Mp 208-210 ${ }^{\circ} \mathrm{C}$; IR (ATR): 3750-3200, 2220, 1705, 1643, 1599, $1265 \mathrm{~cm}^{-1}$; ${ }^{1} \mathrm{H}$ NMR (400 MHz, DMSO- $\left.d_{6}\right): 1.28(3 \mathrm{H}, \mathrm{t}, J=7.2 \mathrm{~Hz}), 4.22(2 \mathrm{H}, \mathrm{q}, J=7.2 \mathrm{~Hz}), 6.88(1 \mathrm{H}, \mathrm{s}), 7.04$ (2H, br s), $7.99(1 \mathrm{H}, \mathrm{s}) ;{ }^{13} \mathrm{C}$ NMR (100 MHz, DMSO-d $): 14.1\left(\mathrm{CH}_{3}\right), 60.7\left(\mathrm{CH}_{2}\right), 116.1$, $137.7\left(\mathrm{CH}_{\text {arom }}\right), 92.2,116.3,138.6,154.1\left(\mathrm{C}_{\text {arom }}\right), 115.5(\mathrm{CN}), 162.9(\mathrm{CO})$; HRMS $\left(\mathrm{ESI}^{+}\right)$ calcd for $\mathrm{C}_{10} \mathrm{H}_{10} \mathrm{ClN}_{2} \mathrm{O}_{2}(\mathrm{M}+\mathrm{H})^{+} 225.0431$, found 225.0442 .

\subsubsection{Ethyl 2-chloro-5-cyano-4-iodobenzoate (6)}

To a solution of compound 5 (1.60 g, $7.1 \mathrm{mmol}, 1$ equiv) in diiodomethane (5 mL) was added isoamyl nitrite $(1.8 \mathrm{~mL}, 13.4 \mathrm{mmol}, 1.88$ equiv) under argon atmosphere. The reaction mixture was stirred at room temperature for $45 \mathrm{~min}$, warmed to $80^{\circ} \mathrm{C}$ and stirred for $3 \mathrm{~h}$. The mixture was diluted with $\mathrm{CH}_{2} \mathrm{Cl}_{2}$ and washed with water and a saturated $\mathrm{NaCl}$ aqueous solution. The organic layer was dried over $\mathrm{MgSO}_{4}$, filtered and concentrated under reduced pressure. Residue was purified by column chromatography (pure cyclohexane then EtOAc/cyclohexane 1:99 to 5:95) to give compound 6 (2.01 g, $6.0 \mathrm{mmol}, 84 \%)$ as a white powder. $R f=0.5$ (EtOAc/cyclohexane 1:5). Mp 108-110 ${ }^{\circ} \mathrm{C}$; IR (ATR): 2232, 1727, 1575, 1449, $1245 \mathrm{~cm}^{-1}$; ${ }^{1} \mathrm{H}$ NMR (400 MHz, DMSO- $\left.d_{6}\right): 1.32(3 \mathrm{H}, \mathrm{t}, J=7.6 \mathrm{~Hz}), 4.33(2 \mathrm{H}, \mathrm{q}$, $J=7.6 \mathrm{~Hz}), 8.23(1 \mathrm{H}, \mathrm{s}), 8.36(1 \mathrm{H}, \mathrm{s}) ;{ }^{13} \mathrm{C}$ NMR $\left(100 \mathrm{MHz}, \mathrm{DMSO}-d_{6}\right): 13.9\left(\mathrm{CH}_{3}\right), 62.1$ $\left(\mathrm{CH}_{2}\right), 135.9,140.8$ ( $\left.\mathrm{CH}_{\text {arom }}\right), 105.4,118.3,130.7,136.9$ ( $\left.\mathrm{C}_{\text {arom }}\right), 118.7(\mathrm{CN}), 163.2(\mathrm{CO})$; HRMS $\left(\mathrm{ESI}^{+}\right)$calcd for $\mathrm{C}_{10} \mathrm{H}_{8} \mathrm{ClINO}_{2}(\mathrm{M}+\mathrm{H})^{+} 335.9288$, found 335.9302 .

\subsubsection{4-Chloro-5-(hydroxymethyl)-2-iodobenzaldehyde (7)}

To a stirred solution of compound 6 (2.00 g, $5.9 \mathrm{mmol}, 1$ equiv) in toluene $(40 \mathrm{~mL})$ at $-78{ }^{\circ} \mathrm{C}$ under argon atmosphere, was added dropwise a solution of DIBAL-H in toluene (1 M, $19.1 \mathrm{mmol}, 3.2$ equiv). The reaction mixture was stirred at $-78^{\circ} \mathrm{C}$ for $1 \mathrm{~h} 30 \mathrm{~min}$, warmed to

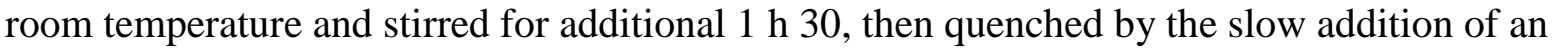
aqueous $\mathrm{HCl}$ solution $(1 \mathrm{M})$. The solution was extracted with EtOAc, the organic layers were washed with brine, dried over $\mathrm{MgSO}_{4}$ and concentrated under reduced pressure. The crude 
product was triturated with cyclohexane yielding the compound $7(1.54 \mathrm{~g}, 5.2 \mathrm{mmol}, 87 \%)$ as a pale yellowish powder. $R f=0.3$ (EtOAc/cyclohexane 1:4). Mp 102-104 ${ }^{\circ} \mathrm{C}$; IR (ATR): 3524-3050, 1678, 1579, 1371, $1043 \mathrm{~cm}^{-1}$; ${ }^{1} \mathrm{H}$ NMR (400 MHz, DMSO-d $)$ ): 4.54 (2H, d, $J=6.0 \mathrm{~Hz}), 5.65(1 \mathrm{H}, \mathrm{t}, J=6.0 \mathrm{~Hz}, \mathrm{OH}), 7.94(1 \mathrm{H}, \mathrm{s}), 8.12(1 \mathrm{H}, \mathrm{s}), 9.94(1 \mathrm{H}, \mathrm{s}, \mathrm{CHO}) ;{ }^{13} \mathrm{C}$ NMR (100 MHz, DMSO-d $\left.d_{6}\right): 59.7\left(\mathrm{CH}_{2}\right), 128.6,139.6\left(\mathrm{CH}_{\text {arom }}\right), 98.8,133.8,137.6,140.9$ $\left(\mathrm{C}_{\text {arom }}\right), 194.7(\mathrm{CO})$; HRMS $\left(\mathrm{ESI}^{+}\right)$calcd for $\mathrm{C}_{9} \mathrm{H}_{9} \mathrm{ClIO}_{2}\left(\mathrm{M}-\mathrm{H}_{2} \mathrm{O}+\mathrm{CH}_{3} \mathrm{OH}+\mathrm{H}\right)^{+} 310.9336$, found 310.9333 .

\subsubsection{4-Chloro-5-(hydroxymethyl)-2-(2-(trimethylsilyl)ethynyl)benzaldehyde (8)}

To a solution of compound 7 (3.65 g, $12.4 \mathrm{mmol}, 1$ equiv) in triethylamine $(60 \mathrm{~mL})$, under argon atmosphere, were successively added $\mathrm{CuI}$ (96 mg, $0.5 \mathrm{mmol}, 4 \mathrm{~mol} \%), \mathrm{PdCl}_{2}\left(\mathrm{PPh}_{3}\right)_{2}$ (176 mg, $0.25 \mathrm{mmol}, 2 \mathrm{~mol} \%$ ) and trimethylsilylacetylene ( $4.5 \mathrm{~mL}, 31 \mathrm{mmol}, 2.5$ equiv). The mixture was stirred at $50{ }^{\circ} \mathrm{C}$ for $3 \mathrm{~h}$. The solvent was removed in vacuo and the crude material was purified by filtration over silica gel with $300 \mathrm{~mL}$ of EtOAc/cyclohexane 2:8. The filtrate was concentrated under reduced pressure and the residue was triturated with pentane yielding compound $\mathbf{8}(2.87 \mathrm{~g}, 10.8 \mathrm{mmol}, 87 \%)$ as a pale brown powder. $R f=0.4$ (EtOAc/cyclohexane 1:4). Mp 91-93 ${ }^{\circ} \mathrm{C}$; IR (ATR): 3650-3273, 1697, 1595, $1235 \mathrm{~cm}^{-1}$; ${ }^{1} \mathrm{H}$ NMR (400 MHz, DMSO-d6): $0.27\left(9 \mathrm{H}, \mathrm{s}, 3 \mathrm{CH}_{3}\right), 4.60(2 \mathrm{H}, \mathrm{d}, J=7.2 \mathrm{~Hz}), 5.69(1 \mathrm{H}, \mathrm{t}$, $J=7.2 \mathrm{~Hz}, \mathrm{OH}), 7.72(1 \mathrm{H}, \mathrm{s}), 8.00(1 \mathrm{H}, \mathrm{s}), 10.35(1 \mathrm{H}, \mathrm{s}, \mathrm{CHO}) ;{ }^{13} \mathrm{C}$ NMR $(100 \mathrm{MHz}$, DMSO- $\left.d_{6}\right)$ : -0.4 (3 $\left.\mathrm{CH}_{3}\right), 59.8\left(\mathrm{CH}_{2}\right), 126.1,133.1$ ( $\left.\mathrm{CH}_{\text {arom }}\right), 98.9,102.9,124.6,134.4,136.7$, $141.7\left(\mathrm{C}_{\text {alkyne }}+\mathrm{C}_{\text {arom }}\right), 190.2(\mathrm{CO}) ; \mathrm{HRMS}\left(\mathrm{ESI}^{+}\right)$calcd for $\mathrm{C}_{13} \mathrm{H}_{16} \mathrm{ClO}_{2} \mathrm{Si}(\mathrm{M}+\mathrm{H})^{+}$ 267.0608, found 267.0606.

\subsubsection{6-Chloro-7-(hydroxymethyl)isoquinoline (9)}

A $10 \mathrm{~mL}$ CEM Discover microwave tube was charged with compound $\mathbf{8}$ (500 $\mathrm{mg}$, $1.87 \mathrm{mmol}, 1$ equiv) and $5 \mathrm{~mL}$ of a solution of ammonia in methanol $(7 \mathrm{M})$. The reaction flask was sealed and irradiated for 15 min (Discover mode, Control Type $=$ Standard, $\mathrm{P}=75 \mathrm{~W}, \mathrm{~T}=130^{\circ} \mathrm{C}$ ). The solvent was removed under reduced pressure. Residue was purified by flash chromatography (EtOAc/cyclohexane 7:3 to 10:0) yielding the isoquinoline 9 (276 $\mathrm{mg}, 1.42 \mathrm{mmol}, 76 \%)$ as a purple powder. $R f=0.3$ (EtOAc/cyclohexane 7:3). Mp 138-140 ${ }^{\circ} \mathrm{C}$; IR (ATR): $3500-2965,1626,1436,1177 \mathrm{~cm}^{-1} ;{ }^{1} \mathrm{H}$ NMR (400 MHz, DMSO- $\left.d_{6}\right)$ : $4.73(2 \mathrm{H}, \mathrm{d}, J=5.2 \mathrm{~Hz}), 5.68(1 \mathrm{H}, \mathrm{t}, J=5.2 \mathrm{~Hz}, \mathrm{OH}), 7.80(1 \mathrm{H}, \mathrm{d}, J=6.0 \mathrm{~Hz}), 8.12(1 \mathrm{H}, \mathrm{s})$, $8.25(1 \mathrm{H}, \mathrm{s}), 8.51(1 \mathrm{H}, \mathrm{d}, J=6.0 \mathrm{~Hz}), 9.37(1 \mathrm{H}, \mathrm{s}) ;{ }^{13} \mathrm{C}$ NMR $\left(100 \mathrm{MHz}, \mathrm{DMSO}-d_{6}\right): 60.5$ $\left(\mathrm{CH}_{2}\right), 119.2,125.9,126.1,143.3,152.2\left(\mathrm{CH}_{\text {arom }}\right), 126.7,134.2,134.8,139.3\left(\mathrm{C}_{\text {arom }}\right) ; \mathrm{HRMS}$ $\left(\mathrm{ESI}^{+}\right)$calcd for $\mathrm{C}_{10} \mathrm{H}_{9} \mathrm{CINO}(\mathrm{M}+\mathrm{H})^{+}$194.0373, found 194.0366.

\subsubsection{6-Chloroisoquinoline-7-carbaldehyde (10)}

To a solution of compound 9 (3.73 g, $19.3 \mathrm{mmol}, 1$ equiv) in $\mathrm{CHCl}_{3}(175 \mathrm{~mL})$ was added $\mathrm{MnO}_{2}(5.02 \mathrm{~g}, 57.8 \mathrm{mmol}, 3$ equiv). The mixture was stirred at reflux for $36 \mathrm{~h}$, filtered through a pad of Celite and washed with EtOAc. The filtrate was concentrated in vacuo. The crude product was triturated with cyclohexane and diisopropyl ether yielding compound $\mathbf{1 0}$ (3.28 g, $17.1 \mathrm{mmol}, 88 \%)$ as a purple powder. $R f=0.2\left(\mathrm{CH}_{2} \mathrm{Cl}_{2} / \mathrm{EtOAc} 9: 1\right) . \mathrm{Mp} 155-157{ }^{\circ} \mathrm{C}$; IR (ATR): 1692, 1617, $1410 \mathrm{~cm}^{-1} ;{ }^{1} \mathrm{H}$ NMR (400 MHz, DMSO- $\left.d_{6}\right): 7.90(1 \mathrm{H}, \mathrm{d}, J=6.0 \mathrm{~Hz})$, $8.30(1 \mathrm{H}, \mathrm{s}), 8.68(1 \mathrm{H}, \mathrm{d}, J=6.0 \mathrm{~Hz}), 8.78(1 \mathrm{H}, \mathrm{s}), 9.57(1 \mathrm{H}, \mathrm{s}), 10.44(1 \mathrm{H}, \mathrm{s}, \mathrm{CHO}) ;{ }^{13} \mathrm{C}$ NMR (100 MHz, DMSO-d $\left.d_{6}\right): 119.5,127.9,132.5,146.2,154.4\left(\mathrm{CH}_{\text {arom }}\right), 126.0,131.0,135.1$, $138.0\left(\mathrm{C}_{\text {arom }}\right), 189.6(\mathrm{CO})$; HRMS $\left(\mathrm{ESI}^{+}\right)$calcd for $\mathrm{C}_{10} \mathrm{H}_{7} \mathrm{ClNO}(\mathrm{M}+\mathrm{H})^{+} 192.0216$, found 192.0225 . 


\subsubsection{6-Chloro-5-nitroisoquinoline-7-carbaldehyde (11)}

To a solution of compound $\mathbf{1 0}(1.35 \mathrm{~g}, 7.05 \mathrm{mmol}, 1$ equiv) in concentrated sulfuric acid $(15 \mathrm{~mL})$ was added dropwise a $65 \%$ nitric acid solution $(0.6 \mathrm{~mL}, 8.45 \mathrm{mmol}, 1.2$ equiv). After stirring overnight at room temperature the reaction mixture was poured into ice/water, and filtered through a pad of Celite. Portions of solid $\mathrm{NaHCO}_{3}$ were added to the filtrate (until $\mathrm{pH}>7$ ) before extraction with EtOAc. The organic layers were washed with brine, dried over $\mathrm{MgSO}_{4}$ and concentrated under reduced pressure. The crude material was triturated with diethyl ether yielding compound $11(1.45 \mathrm{~g}, 6.13 \mathrm{mmol}, 87 \%)$ as a pale brown powder. $R f=0.4\left(\mathrm{CH}_{2} \mathrm{Cl}_{2} / \mathrm{EtOAc} 9: 1\right) . \mathrm{Mp} 186-187{ }^{\circ} \mathrm{C}$; IR (ATR): 1692, 1613, 1523 , $1268 \mathrm{~cm}^{-1} ;{ }^{1} \mathrm{H}$ NMR $\left(500 \mathrm{MHz}, \mathrm{DMSO}-d_{6}\right): 7.73\left(1 \mathrm{H}, \mathrm{dt}, J_{1}=6.0 \mathrm{~Hz} ; J_{2}=0.8 \mathrm{~Hz}\right), 8.86$ $(1 \mathrm{H}, \mathrm{d}, J=6.0 \mathrm{~Hz}), 9.07(1 \mathrm{H}, \mathrm{d}, J=0.8 \mathrm{~Hz}), 9.78(1 \mathrm{H}, \mathrm{d}, J=0.8 \mathrm{~Hz}), 10.39(1 \mathrm{H}, \mathrm{s}, \mathrm{CHO})$; ${ }^{13} \mathrm{C}$ NMR (100 MHz, DMSO- $\left.d_{6}\right)$ : 113.3, 134.5, 148.6, $154.9\left(\mathrm{CH}_{\text {arom }}\right), 125.7,127.2,129.0$, 130.7, $145.2\left(\mathrm{C}_{\text {arom }}\right), 187.8(\mathrm{CO})$; HRMS $\left(\mathrm{ESI}^{+}\right)$calcd for $\mathrm{C}_{10} \mathrm{H}_{6} \mathrm{ClN}_{2} \mathrm{O}_{3}(\mathrm{M}+\mathrm{H})^{+} 237.0067$, found 237.0078 .

\subsubsection{0-nitropyrido[3,4-g]quinazolin-2-amine (12)}

A $10 \mathrm{~mL}$ CEM Discover microwave tube was charged with compound 11 (100 mg, $0.42 \mathrm{mmol}, 1$ equiv) and guanidine carbonate (100 $\mathrm{mg}, 0.52 \mathrm{mmol}, 1.3$ equiv) in $4 \mathrm{~mL}$ of $\mathrm{N}, \mathrm{N}$-dimethylformamide (99.8\%; for peptide synthesis) resulting in a suspension. The reaction flask was purged with argon for $30 \mathrm{~min}$, sealed and irradiated for $45 \mathrm{~s}$ (Discover Mode, Control Type $=$ Standard, $\mathrm{P}=300 \mathrm{~W}, \mathrm{~T}=166^{\circ} \mathrm{C}$ ). After cooling, the reaction was diluted with EtOAc and filtered through a pad of Celite. The organic layer was washed with water, dried over $\mathrm{MgSO}_{4}$ and concentrated under reduced pressure. Residue was purified by flash chromatography using $\mathrm{CH}_{2} \mathrm{Cl}_{2} / \mathrm{MeOH}$ (99:1 to 97:3) as eluant, yielding the pure compound 12 (50 mg, $0.21 \mathrm{mmol}, 49 \%)$ as an orange powder. $R f=0.3$ (EtOAc). $\mathrm{Mp}>245^{\circ} \mathrm{C}$ (decomposition); IR (ATR): 3300-3000, 1700, 1623, 1608, 1576, $1507 \mathrm{~cm}^{-1}$; ${ }^{1} \mathrm{H}$ NMR $\left(500 \mathrm{MHz}, \mathrm{DMSO}-d_{6}\right): 7.52\left(1 \mathrm{H}, \mathrm{d}, J=6.0 \mathrm{~Hz}, \mathrm{H}_{9}\right), 8.00(1 \mathrm{H}, \mathrm{br}$ s, NH), $8.09(1 \mathrm{H}$, br s, NH), $8.56\left(1 \mathrm{H}, \mathrm{d}, J=6 \mathrm{~Hz}, \mathrm{H}_{8}\right), 8.99\left(1 \mathrm{H}, \mathrm{s}, \mathrm{H}_{5}\right), 9.53\left(1 \mathrm{H}, \mathrm{s}, \mathrm{H}_{6}\right), 9.58\left(1 \mathrm{H}, \mathrm{s}, \mathrm{H}_{4}\right) ;{ }^{13} \mathrm{C}$ NMR (100 MHz, DMSO- $\left.d_{6}\right): 112.2\left(\mathrm{C}_{9}\right), 134.2\left(\mathrm{C}_{5}\right), 146.1\left(\mathrm{C}_{8}\right), 155.0\left(\mathrm{C}_{6}\right), 165.8\left(\mathrm{C}_{4}\right)$, $119.5\left(\mathrm{C}_{4 \mathrm{a}}\right), 121.8\left(\mathrm{C}_{5 \mathrm{~b}}\right), 128.5\left(\mathrm{C}_{9 \mathrm{~b}}\right), 136.2\left(\mathrm{C}_{10}\right), 141.7\left(\mathrm{C}_{10 \mathrm{a}}\right), 161.2\left(\mathrm{C}_{2}\right)$; HRMS $\left(\mathrm{ESI}^{+}\right)$ calcd for $\mathrm{C}_{11} \mathrm{H}_{8} \mathrm{~N}_{5} \mathrm{O}_{2}(\mathrm{M}+\mathrm{H})^{+} 242.0673$, found 242.0682. HPLC (method I): purity $\geq 98 \%$, $\mathrm{t}_{\mathrm{R}}=15.8 \mathrm{~min}$.

\subsubsection{Pyrido[3,4-g]quinazoline-2,10-diamine (13)}

To a suspension of compound $12(50 \mathrm{mg}, 0.21 \mathrm{mmol})$ in $40 \mathrm{~mL}$ of $1: 1$ mixture of anhydrous dichloromethane and anhydrous methanol was added palladium on charcoal (10\% wt, $9 \mathrm{mg}$, $0.008 \mathrm{mmol}$ ). The mixture was stirred under $1 \mathrm{~atm} . \mathrm{H}_{2}$ for $3 \mathrm{~h}$, and filtered through Celite. The Celite pad was washed with a mixture of $\mathrm{CH}_{2} \mathrm{Cl}_{2} / \mathrm{MeOH}$ 1:1. Combined filtrates were concentrated under reduced pressure to give the title compound without further purification (43 mg, $0.21 \mathrm{mmol}$, quantitative yield) as a red powder. $R f=0.2$ (EtOAc). $\mathrm{Mp}>250{ }^{\circ} \mathrm{C}$ (decomposition); IR (ATR): $3400-3000,1646,1614 \mathrm{~cm}^{-1}$; ${ }^{1} \mathrm{H}$ NMR (500 MHz, DMSO- $d_{6}$ ): $6.24\left(2 \mathrm{H}\right.$, br s, $\left.\mathrm{NH}_{2}\right), 7.02\left(2 \mathrm{H}\right.$, br s, $\left.\mathrm{NH}_{2}\right), 7.85(1 \mathrm{H}, \mathrm{s}), 7.97(1 \mathrm{H}, \mathrm{d}, J=6.2 \mathrm{~Hz}), 8.20(1 \mathrm{H}, \mathrm{d}$, $J=6.2 \mathrm{~Hz}), 9.23(1 \mathrm{H}, \mathrm{s}), 9.36(1 \mathrm{H}, \mathrm{s}) ;{ }^{13} \mathrm{C}$ NMR (100 MHz, DMSO-d $)$ : 113.6, 115.4, 139.4, 154.8, $164.8\left(\mathrm{CH}_{\text {arom }}\right), 118.9,121.0,124.4,135.1,136.0,158.7\left(\mathrm{C}_{\text {arom }}\right)$; HRMS $\left(\mathrm{ESI}^{+}\right)$calcd for $\mathrm{C}_{11} \mathrm{H}_{10} \mathrm{~N}_{5}(\mathrm{M}+\mathrm{H})^{+} 212.0936$, found 212.0941 . HPLC (method II): purity $\geq 95 \%$, $\mathrm{t}_{\mathrm{R}}=8.1 \mathrm{~min}$. 


\subsubsection{Pyrido[3,4-g]quinazolin-2-amine (14)}

To an ice/water bath cooled solution of compound $13(57 \mathrm{mg}, 0.27 \mathrm{mmol}, 1$ equiv) in a $5 \mathrm{M}$ aqueous solution of $\mathrm{HCl}(2 \mathrm{~mL})$, was added dropwise a solution of $\mathrm{NaNO}_{2}(24 \mathrm{mg}$, $0.35 \mathrm{mmol}, 1.3$ equiv) in water $(2 \mathrm{~mL})$ and the mixture was stirred at $0{ }^{\circ} \mathrm{C}$ for $1 \mathrm{~h}$. Then, an aqueous solution of $\mathrm{H}_{3} \mathrm{PO}_{2}(50 \% \mathrm{wt}, 0.5 \mathrm{~mL})$ was added and the mixture was stirred at room temperature for $24 \mathrm{~h}$. The mixture was then diluted with water and basified by addition of a saturated aqueous $\mathrm{NaHCO}_{3}$ solution. The aqueous layer was extracted with EtOAc and the organic layers were dried over $\mathrm{MgSO}_{4}$ and concentrated. Residue was purified by flash chromatography on $\mathrm{Et}_{3} \mathrm{~N}$ neutralized silica gel using $\mathrm{CH}_{2} \mathrm{Cl}_{2} / \mathrm{MeOH} / \mathrm{Et}_{3} \mathrm{~N}$ 96:3:1 as eluant. The residue was dissolved in EtOAc and further washed with a diluted $\mathrm{NaHCO}_{3}$ aqueous solution. The organic phase was dried over $\mathrm{MgSO}_{4}$ and evaporated yielding the title compound $14(15 \mathrm{mg}, 0.08 \mathrm{mmol}, 29 \%)$ as a yellow powder. $R f=0.3\left(\mathrm{CH}_{2} \mathrm{Cl}_{2} / \mathrm{MeOH} / \mathrm{Et}_{3} \mathrm{~N}\right.$ 96:3:1). Mp > $220^{\circ} \mathrm{C}$ (decomposition); IR (ATR): 3350-3100, 1653, 1624, 1579, $1558 \mathrm{~cm}^{-1}$; ${ }^{1} \mathrm{H}$ NMR (400 MHz, DMSO-d $)$ : 7.32 (2H, br s, NH$), 7.78(1 \mathrm{H}, \mathrm{d}, J=6.0 \mathrm{~Hz}), 7.84(1 \mathrm{H}, \mathrm{s})$, $8.36(1 \mathrm{H}, \mathrm{d}, J=6.0 \mathrm{~Hz}), 8.73(1 \mathrm{H}, \mathrm{s}), 9.40(1 \mathrm{H}, \mathrm{s}), 9.49(1 \mathrm{H}, \mathrm{s}) ;{ }^{13} \mathrm{C} \mathrm{NMR}(100 \mathrm{MHz}$, DMSO- $\left.d_{6}\right): 118.0,119.3,130.5,142.7,154.8,165.4\left(\mathrm{CH}_{\text {arom }}\right), 119.7,124.0,137.5,149.4$, $160.3\left(\mathrm{C}_{\text {arom }}\right)$; HRMS $\left(\mathrm{ESI}^{+}\right)$calcd for $\mathrm{C}_{11} \mathrm{H}_{9} \mathrm{~N}_{4}(\mathrm{M}+\mathrm{H})^{+}$197.0827, found 197.0835. HPLC (method III): purity $\geq 99 \%, \mathrm{t}_{\mathrm{R}}=4.8 \mathrm{~min}$.

\subsection{Crystallography}

Recombinant CLK1 was expressed and purified as previously described [33]. Apo crystals were obtained using sitting vapour diffusion method at $4{ }^{\circ} \mathrm{C}$ and the condition containing $30 \%$ 1,2-propanediol, $10 \%$ glycerol and $50 \mathrm{mM} \mathrm{Na} / \mathrm{K}$ phosphate. Soaking was performed overnight using the reservoir solution supplemented with 5-10 $\mathrm{mM}$ compounds and $25 \%$ glycerol. Diffraction data were collected at Diamond Light Source, beamline I03 using X-ray at $0.97625 \AA$ wavelength, and were processed and scaled with Mosflm [34] and Scala [35], respectively. Structures were solved by molecular replacement method using Phaser [36] and the coordinates of published CLK1 structure [33]. Model rebuilding was performed in COOT [37], and the structures were refined using REFMAC [38]. Geometric correctness was verified using MOLPROBITY [39]. The data collection and refinement statistics are summarized in the table below.

\section{Complex PDB accession code}

$\operatorname{Resolution}^{\mathrm{a}}(\AA)$
Spacegroup
Cell dimensions
No. unique reflections ${ }^{\mathrm{a}}$
Completeness
I/ $\mathrm{II}^{\mathrm{a}}$
$\mathrm{R}_{\text {merge }^{\mathrm{a}}}$

CLK1-13

$$
\text { 5J1V }
$$

Data Collection

$\begin{array}{ll}35.47-2.52 & 35.59-2.42 \\ (2.66-2.52) & (2.55-2.42) \\ P 2_{1} & P 21 \\ a=56.5, b=116.0, & a=56.6, b=118.0, \\ c=90.1 \AA & c=90.5 \AA \\ \alpha=\gamma=90.0^{\circ}, \beta=99.3^{\circ} & \alpha=\gamma=90.0^{\circ}, \beta=99.6^{\circ} \\ 38,700(5,626) & 44,729(6,537) \\ 99.8(99.8) & 99.9(99.9) \\ 7.6(2.0) & 8.3(2.0) \\ 0.119(0.829) & 0.082(0.599)\end{array}$

\section{CLK1-14 \\ $\underline{5 J 1 W}$}




\begin{tabular}{|c|c|c|}
\hline Complex & CLK1-13 & CLK1-14 \\
\hline PDB accession code & $\underline{5 J 1 V}$ & 5J1W \\
\hline Redundancy ${ }^{\mathrm{a}}$ & $4.8(4.5)$ & $3.4(3.4)$ \\
\hline \multicolumn{3}{|c|}{ Refinement } \\
\hline $\begin{array}{l}\text { No. atoms in refinement } \\
(\mathrm{P} / \mathrm{L} / \mathrm{O})^{\underline{b}}\end{array}$ & $7,927 / 48 / 107$ & $8,015 / 45 / 193$ \\
\hline $\mathrm{B}$ factor $(\mathrm{P} / \mathrm{L} / \mathrm{O})^{\mathrm{b}}\left(\AA^{2}\right)$ & $72 / 36 / 62$ & $66 / 32 / 64$ \\
\hline $\mathrm{R}_{\text {fact }}(\%)$ & 19.9 & 18.9 \\
\hline $\mathrm{R}_{\text {free }}(\%)$ & 24.4 & 22.8 \\
\hline rms deviation bond ${ }^{\mathrm{c}}(\AA)$ & 0.011 & 0.013 \\
\hline rms deviation angle ${ }^{\mathrm{c}}\left(^{\circ}\right)$ & 1.2 & 1.3 \\
\hline \multicolumn{3}{|c|}{ Molprobity Ramachandran } \\
\hline Favour $(\%)$ & 95.89 & 95.51 \\
\hline Allowed (\%) & 4.11 & 4.49 \\
\hline \multicolumn{3}{|c|}{$\begin{array}{l}\text { a) Values in brackets show the statistics for the highest resolution shells. } \\
\text { b) P/L/O indicate protein, ligand molecules presented in the active sites, and other } \\
\text { (water and solvent molecules), respectively. } \\
\text { c) rms indicates root-mean-square. }\end{array}$} \\
\hline
\end{tabular}

\subsection{In vitro kinase inhibition assays}

Buffer A: $10 \mathrm{mM} \mathrm{MgCl} 2,1 \mathrm{mM}$ ethylene glycol-bis(2-aminoethylether)- $N, N, N^{\prime}, N^{\prime}$-tetraacetic acid (EGTA), $1 \mathrm{mM}$ dithiothreitol (DTT), $25 \mathrm{mM}$ Tris- $\mathrm{HCl} \mathrm{pH}$ 7.5, $50 \mu \mathrm{g}$ heparin/mL.

Buffer B: $60 \mathrm{mM} \beta$-glycerophosphate, $15 \mathrm{mM}$ p-nitrophenylphosphate, $25 \mathrm{mM} 3-(N$ morpholino)propanesulfonic acid (Mops) (pH 7.2), $5 \mathrm{mM}$ EGTA, $15 \mathrm{mM} \mathrm{MgCl}, 1 \mathrm{mM}$ DTT, $1 \mathrm{mM}$ sodium vanadate, $1 \mathrm{mM}$ phenylphosphate.

Kinase activities were assayed in buffer $\mathrm{A}$ or $\mathrm{B}$, at $30^{\circ} \mathrm{C}$, at a final adenosine triphosphate (ATP) concentration of $15 \mu \mathrm{M}$. Blank values were subtracted and activities expressed in $\%$ of the maximal activity, i.e. in the absence of inhibitors. Controls were performed with appropriate dilutions of dimethylsulfoxide (DMSO).

CDK5/p25 (human, recombinant) was prepared as previously described [40] and [41]. Its kinase activity was assayed in buffer $\mathrm{B}$, with $1 \mathrm{mg}$ histone $\mathrm{H} 1 / \mathrm{mL}$, in the presence of $15 \mu \mathrm{M}$ $\left[\gamma_{-}{ }^{33} \mathrm{P}\right]$ ATP $(3000 \mathrm{Ci} / \mathrm{mmol} ; 10 \mathrm{mCi} / \mathrm{mL})$ in a final volume of $30 \mu \mathrm{L}$. After $30 \mathrm{~min}$ incubation at $30{ }^{\circ} \mathrm{C}, 25 \mu \mathrm{L}$ aliquots of supernatant were spotted onto $2.5 \times 3 \mathrm{~cm}$ pieces of Whatman P81 phosphocellulose paper, and, $20 \mathrm{~s}$ later, the filters were washed five times (for at least $5 \mathrm{~min}$ each time) in a solution of $10 \mathrm{~mL}$ phosphoric acid/L of water. The wet filters were counted in the presence of $1 \mathrm{~mL}$ ACS (Amersham) scintillation fluid.

GSK-3 $\alpha / \beta$ (porcine brain, native) was assayed, as described for CDK5/p25 but in buffer A and using a GSK-3 specific substrate (GS-1: YRRAAVPPSPSLSRHSSPHQSpEDEEE) (pS stands for phosphorylated serine) [42]. GS-1 was synthesized by Millegen (Labege, France). 
$C K 1 \delta / \varepsilon$ (porcine brain, native) was assayed as described for CDK5/p25 but using the CK1specific peptide substrate RRKHAAIGpSAYSITA [43], obtained from Millegen (Labege, France).

DYRK1A (rat, recombinant, expressed in Escherichia coli as a glutathione transferase (GST) fusion protein) was purified by affinity chromatography on glutathione-agarose and assayed as described for CDK5/p25 using myelin basic protein $(1 \mathrm{mg} / \mathrm{mL})$ as a substrate.

CLK1 (human, recombinant, expressed in E. coli as GST fusion protein) was assayed in buffer A (+0.15 mg BSA/ml) with RS peptide (GRSRSRSRSRSR) (1 $\mu \mathrm{g} /$ assay).

\section{Acknowledgements}

The authors thank Aurélie Job for HPLC analysis. The Auvergne Region (Jeune Chercheur Program) is acknowledged for funding by W. Z., F. A., F. G. and P. M. as well as the French Ministry of Higher Education and Research for Y. J. E. PhD fellowship. This work was also supported by "Fonds Unique Interministériel" TRIAD project, "Fondation Jérôme Lejeune" and EEC FP7 grant BLUEGENICS (LM).

\section{References}

1.

[1]

G.V.W. Johnson, W.H. Stoothoff

J. Cell Sci., 117 (2004), pp. 5721-5729

Full Text via CrossRef

2.

[2]

M. Flajolet, G. He, M. Heiman, A. Lin, A.C. Nairn, P. Greengard

P.N.A.S., 104 (2007), pp. 4159-4164

Full Text via CrossRef

3.

[3]

L. Meijer, M. Flajolet, P. Greengard

Trends Pharmacol. Sci., 25 (2004), pp. 471-480

Article

[4]

S.-R. Ryoo, H.K. Jeong, C. Radnaabazar, J.-J. Yoo, H.-J. Cho, H.W. Lee, I.-S.

Kim, Y.-H. Cheon, Y.S. Ahn, S.-H. Chung, W.-J. Song

○ J. Biol. Chem., 282 (2007), pp. 34850-34857

- Full Text via CrossRef

- [5]

- A. Arias-Vásquez, Y.S. Aulchenko, A. Isaacs, A. van Oosterhout, K. Sleegers,

A. Hofman, C. van Broeckhoven, B.A. Oostra, M. Breteler, C.M. van Dujin

- J. Neurol., 255 (2008), pp. 655-662

- Full Text via CrossRef 
4.

$\circ \quad[6]$

- G. Li, H. Yin, J. Kuret

○ J. Biol. Chem., 279 (2004), pp. 15938-15945

- Full Text via CrossRef

5 .

[7]

B. Smith, F. Medda, V. Gokhale, T. Dunckley, C. Hulme

ACS Chem. Neurosci., 3 (2012), pp. 857-872

Full Text via CrossRef

6.

$\circ \quad[8]$

- P. Jain, C. Karthikeyan, N.S. Moorthy, D.K. Waiker, A.K. Jain, P. Trivedi

- Curr. Drug Targets, 15 (2014), pp. 539-550

- Full Text via CrossRef

7.

○ [9]

- Kinase-disease associations. Available online:

http://www.cellsignal.com/common/content/content.jsp?id=science-tableskinase-disease\#sthash.r9EVxJ2m.dpuf; [accessed 22/04/15].

8 .

$\circ \quad[10]$

- Y. Loidreau, E. Deau, P. Marchand, M.-R. Nourisson, C. Logé, G. Coadou, L. Meijer, T. Besson

○ Eur. J. Med. Chem., 92 (2015), pp. 124-134

- $\underline{\text { Article }}$

9.

○ [11]

- L.H. Franco, E. Bal de Kier Joffé, L. Puricelli, M. Tatian, A.M. Seldes, J.A. Palermo

J. Nat. Prod., 61 (1998), pp. 1130-1132

- Full Text via CrossRef

○ [12]

- L.H. Franco, J.A. Palermo

- Chem. Pharm. Bull., 51 (2003), pp. 975-977

- View Record in Scopus

10.

$\circ \quad[13]$

- M. Gompel, M. Leost, E. Bal de Kier Joffé, L. Puricelli, L.H. Franco, J. Palermo, L. Meijer

○ Bioorg. Med. Chem. Lett., 14 (2004), pp. 1703-1707

- Article

11 .

$\circ \quad[14]$

- E. Rossignol, A. Youssef, P. Moreau, M. Prudhomme, F. Anizon

- Tetrahedron, 63 (2007), pp. 10169-10176

- Article 
$\circ \quad[15]$

- E. Rossignol, E. Debiton, D. Fabbro, P. Moreau, M. Prudhomme, F. Anizon

- Anti-Cancer Drugs, 19 (2008), pp. 789-792

- Full Text via CrossRef

13.

$\circ \quad[16]$

- R. Akué-Gédu, E. Debiton, Y. Ferandin, L. Meijer, M. Prudhomme, F. Anizon, P. Moreau

○ Bioorg. Med. Chem., 17 (2009), pp. 4420-4424

Article

14.

$\circ \quad[17]$

- F. Giraud, G. Alves, E. Debiton, L. Nauton, V. Théry, E. Durieu, Y. Ferandin, O. Lozach, L. Meijer, F. Anizon, E. Pereira, P. Moreau

○ J. Med. Chem., 54 (2011), pp. 4474-4489

- Full Text via CrossRef

15 .

○ [18]

- T. Owa, H. Yoshino, T. Okauchi, K. Yoshimatsu, Y. Ozawa, N.H. Sugi, T.

Nagasu, N. Koyanagi, K. Kitoh

○ J. Med. Chem., 42 (1999), pp. 3789-3799

- Full Text via CrossRef

16.

$\circ \quad[19]$

- C.-Y. Liu, P. Knochel

- Org. Lett., 7 (2005), pp. 2543-2546

- Full Text via CrossRef

17.

- [20]

- D. Wang, L. Kuang, Z. Li, K. Ding

- Synlett (2008), pp. 69-72

- View Record in Scopus

$\circ \quad[21]$

- W.B. Smith, O. Chenpu Ho

○ J. Org. Chem., 55 (1990), pp. 2543-2545

- Full Text via CrossRef

2.

$\circ \quad[22]$

- L. Wang, G.T. Wang, X. Wang, Y. Tong, G. Sullivan, D. Park, N.M. Leonard, Q. Li, J. Cohen, W.-Z. Gu, H. Zhang, J.L. Bauch, C.G. Jakob, C.W. Hutchins, V.S. Stoll, K. Marsh, S.H. Rosenberg, H.L. Sham, N.-H. Lin

- J. Med. Chem., 47 (2004), pp. 612-626

- Full Text via CrossRef

3.

○ [23]

- N. Miyaura, A. Suzuki

- Org. Synth., 68 (1990), p. 130

4. 
- S.Y. Seo, T.J. Marks

○ Chem. Eur. J., 16 (2010), pp. 5148-5162

- Full Text via CrossRef

5 .

$[25]$

M. Alfonsi, M. Dell'Acqua, D. Facoetti, A. Arcadi, G. Abbiati, E. Rossi

Eur. J. Org. Chem. (2009), pp. 2852-2862

Full Text via CrossRef

6.

$\circ \quad[26]$

- Y. Fujikawa, Y. Urano, T. Komatsu, K. Hanaoka, H. Kojima, T. Terai, H. Inoue, T. Nagano

J. Am. Chem. Soc., 130 (2008), pp. 14533-14543

\section{Full Text via CrossRef}

7.

[27]

- Imbach P., Blas Perez L., Caravatti G., Sheng T., Martiny-Baron G., Furet P. American Patent US Patent US2006/0035897 A1, 2006.

○

8

$\circ \quad[28]$

- V. Suchaud, L. Gavara, F. Giraud, L. Nauton, V. Théry, F. Anizon, P. Moreau

- Bioorg. Med. Chem., 22 (2014), pp. 4704-4710

- Article

9.

- [29]

- T. Tahtouh, J.M. Elkins, P. Filippakopoulos, M. Soundararajan, G. Burgy, E. Durieu, C. Cochet, R.S. Schmid, D.C. Lo, F. Delhommel, A.E. Oberholzer, L.H. Pearl, F. Carreaux, J.-P. Bazureau, S. Knapp, L. Meijer

○ J. Med. Chem., 55 (2012), pp. 9312-9330

- Full Text via CrossRef

10.

- [30]

- SybylX2.1, Tripos International, 1699 South Hanley Rd., St. Louis, Missouri 63144, USA.

11

$\circ \quad[31]$

- S.A. Hitchcock, L.D. Pennington

- J. Med. Chem., 49 (2006), pp. 7559-7583

- Full Text via CrossRef

12.

- [32]

- E.F. Pettersen, T.D. Goddard, C.C. Huang, G.S. Couch, D.M. Greenblatt, E.C. Meng, T.E. Ferrin

○ J. Comput. Chem., 25 (2004), pp. 1605-1612

- Full Text via CrossRef

13.

$\circ \quad[33]$ 
- A.N. Bullock, S. Das, J.E. Debreczeni, P. Rellos, O. Fedorov, F.H. Niesen, K. Guo, E. Papagrigoriou, A.L. Amos, S. Cho, B.E. Turk, G. Ghosh, S. Knapp

- Structure, 17 (2009), pp. 352-362

\section{- Article}

14.

[34]

H.R. Powell, O. Johnson, A.G.W. Leslie

Acta Cryst. D., 69 (2013), pp. 1195-1203

- Full Text via CrossRef

15 .

$\circ \quad[35]$

- P. Evans

- Acta Cryst. D., 62 (2006), pp. 72-82

- Full Text via CrossRef

16.

$\circ \quad[36]$

- A.J. McCoy, R.W. Grosse-Kunstleve, P.D. Adams, M.D. Winn, L.C. Storoni, R.J. Read

○ J. Appl. Crystallogr., 40 (2007), pp. 658-674

- Full Text via CrossRef

17.

$\circ \quad[37]$

- P. Emsley, B. Lohkamp, W.G. Scott, K. Cowtan

- Acta Cryst. D., 66 (2010), pp. 486-501

- Full Text via CrossRef

18.

$\circ \quad[38]$

- G.N. Murshudov, P. Skubák, A.A. Lebedev, N.S. Pannu, R.A. Steiner, R.A. Nicholls, M.D. Winn, F. Long, A.A. Vagin

- Acta Cryst. D., 67 (2011), pp. 355-367

- Full Text via CrossRef

19.

- [39]

- V.B. Chen, W.B. Arendal III, J.J. Headd, D.A. Keedy, R.M. Immormino, G.J. Kapral, L.W. Murray, J.S. Richardson, D.C. Richardson

- Acta Cryst. D., 66 (2010), pp. 12-21

- Full Text via CrossRef

20.

○ [40]

- S. Leclerc, M. Garnier, R. Hoessel, D. Marko, J.A. Bibb, G.L. Snyder, P. Greengard, J. Biernat, E.-M. Mandelkow, G. Eisenbrand, L. Meijer

- J. Biol. Chem., 276 (2001), pp. 251-260

- Full Text via CrossRef

1.

○ [41]

- S. Bach, M. Knockaert, J. Reinhardt, O. Lozach, S. Schmitt, B. Baratte, M. Koken, S.P. Coburn, L. Tang, T. Jiang, D.C. Liang, H. Galons, J.F. Dierick, L.A. Pina, F. Meggio, F. Totzke, C. Schächtele, A.S. Lerman, A. Carnero, Y. Wan, N. Gray, L. Meijer 
○ J. Biol. Chem., 280 (2005), pp. 31208-31219

- Full Text via CrossRef

2.

- [42]

- A. Primot, B. Baratte, M. Gompel, A. Borgne, S. Liabeuf, J.L. Romette, E.H. Jho, F. Costantini, L. Meijer

○ Protein Expr. Purif., 20 (2000), pp. 394-404

- Article

3.

○ [43]

- J. Reinhardt, Y. Ferandin, L. Meijer

○ Protein Expr. Purif., 54 (2007), pp. 101-109

- Article

Corresponding author. Université Clermont Auvergne, Université Blaise Pascal, Institut de Chimie de Clermont-Ferrand, BP 10448, F-63000 Clermont-Ferrand, France.

Corresponding author. Université Clermont Auvergne, Université Blaise Pascal, Institut de Chimie de Clermont-Ferrand, BP 10448, F-63000 Clermont-Ferrand, France.

1) Both authors (YJE, WZ) equally contributed to this work.

(C) 2016 Elsevier Masson SAS. All rights reserved. 